\title{
Muslim Educational Reform in 20th-Century China: The Case of the Chengda Teachers Academy
}

La réforme éducative musulmane au $x x^{e}$ siècle en Chine: le cas de l'École Chengda

二十世紀中國的穆斯林教育改革：成達師範學校個案研究

\section{Yufeng Mao}

\section{OpenEdition}

\section{Journals}

\section{Electronic version}

URL: http://journals.openedition.org/extremeorient/193

DOI: 10.4000/extremeorient.193

ISSN: 2108-7105

\section{Publisher}

Presses universitaires de Vincennes

\section{Printed version}

Date of publication: 1 November 2011

Number of pages: $143-170$

ISBN: 978-2-84292-334-1

ISSN: 0754-5010

\section{Electronic reference}

Yufeng Mao, « Muslim Educational Reform in 20th-Century China:

The Case of the Chengda Teachers Academy », Extrême-Orient Extrême-Occident [Online], 33 | 2011 ,

Online since 01 November 2014, connection on 10 December 2020. URL : http://

journals.openedition.org/extremeorient/193 ; DOI : https://doi.org/10.4000/extremeorient.193 


\title{
Muslim Educational Reform in 20th-Century China: The Case of the Chengda Teachers Academy
}

\author{
Mao Yufeng
}

From the late Qing to the Republican era, Chinese-speaking Muslim elites engaged in a movement to build new-style schools for Muslim children. ${ }^{1}$ Influenced by the widespread educational reform trends in China at the time, these schools were, typically, no longer attached to mosques, and their curricula emphasized the inclusion of modern secular subjects. They had, nonetheless, a markedly religious character and clearly aimed at improving religious education for Muslims.

What distinguishes Muslims in China from followers of Buddhism, Daoism, Christianity and Catholicism is the ethnic consciousness of the so-called huimin population. Although Muslims lived in various regions of China and thus frequently spoke mutually incomprehensible dialects, there was nevertheless a strong sense of community, deriving not only from a shared religious faith but also from their dietary habits and well-developed professional and business networks (long-distance caravans, butchering, leather-making, restaurant business). Even more important, however, was their shared sense of ethnic exclusion by the Han. The Qing had codified ethnic discrimination against Muslims and imposed harsher penalties on Muslim offenders. In order to combat this discrimination, in the ethnically diverse region of Yunnan, Muslims often took to identifying themselves ethnically, using non-religious terms. ${ }^{2}$ In short, the marked sense of ethnic identity among the so-called huimin population derived simultaneously from bonds of self-identification and from the explicit

1. This article mainly discusses the Chinese-speaking Muslims living outside Xinjiang. Muslims in Xinjiang, including various ethnic communities, also embraced educational reforms that were influenced by modernism and sciences. Since such reforms in this province were complicated by a regional politics involving warlord government, ethnic conflict, and Soviet and Central Asian influences, they are not covered in this paper.

2. For Muslim networks and ethnic identity, see Lipmam, Familiar Strangers and Atwill, The Chinese Sultanate. 
patterns of discrimination imposed by Han society and the state. As a result, the term hui should not be translated simply as "Muslim," since it frequently is used, both by the hui themselves and by the government as referring to an ethnic rather than to a specifically religious identity. ${ }^{3}$

This ethnic awareness shaped Muslim educational reform in China at the turn of the 20th century. Specifically, many Muslim reformers were concerned with the issue of the place of their community in China. For some of the reformers, the attempt to fully integrate the Chinese Muslim population in society proved an important motivation. As a result, the new-style Muslim education aimed to promote Muslim identification with the "Chinese nation," another construct of the 20th century. This article will use the story of one of the most prominent of these new institutions, the Chengda Teachers Academy (Chengda shifan xuexiao, 1925-1941), to illustrate key aspects of Muslim educational reform in the first half of the 20th century.

\section{Background: Traditional Muslim Educational Institutions}

Arab and Persian Muslims started to settle in China during the Tang. They moved along the silk roads (both on land and by the sea) and arrived in cities like Chang'an, Luoyang, Kaifeng, Guangzhou, Quanzhou, Hangzhou and Yangzhou. The number of Muslims who came during the Tang and the Song was small, though, compared with the large number of Muslims who came during the Yuan as soldiers and craftsmen. Once settled in China, Muslims would give their children two kinds of education. One was the same given to Chinese children. Often, in the span of two generations, Muslim immigrants started to take civil service examinations and many succeeded. ${ }^{4}$ During the Yuan dynasty, the authorities gave preferential treatment to the Mongols and the semu, mostly Muslims of Central Asian descent, requiring of them fewer exams and shorter essays. ${ }^{5}$ This in turn further encouraged Muslim families to provide traditional Chinese education (in the form of private academies or individual tutoring) to their children. ${ }^{6}$ During the Yuan era, there were Muslim-sponsored private institutions which provided an education similar to that received by Han children. ${ }^{7}$ These institutions produced a number of Muslim jinshi and juren,

3. Currently Muslims in Taiwan are considered to be of Han ethnicity. This was the result of the Nanjing government's active policy to deny the ethnic nature of Muslim communities in pre-1949 China.

4. Zhou Chuanbin, Xinhua xiangchuan de huizu jiaoyu, p. 39.

5. Ibid., p. 40 .

6. Hu Yunsheng, Chuancheng yu renting: henan huizu lishi bianqian yanjiu, p. 166-167.

7. Ibid., p. 175. 

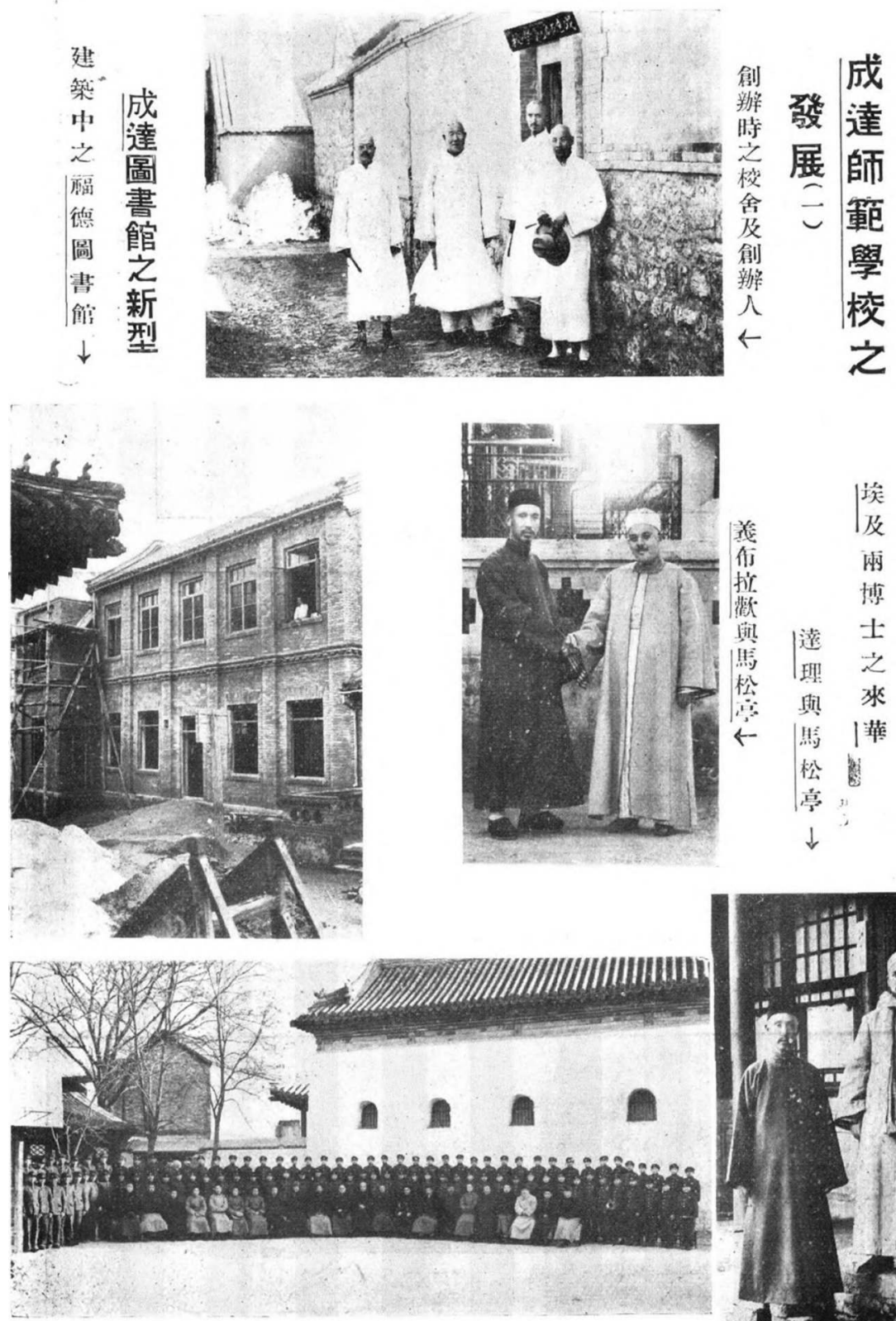

影合生的消豊月一年五十二

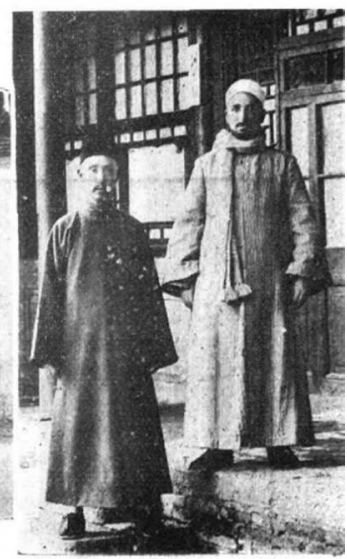

Chengda Teachers Academy, (c) photos published in Yugong 禹貢 (5)11, 1936. 
high-level civil servants chosen by a rigorous literary examination. ${ }^{8}$ While for some Muslims this classical Chinese education became a channel for obtaining wealth and status, many conservative families naturally enough viewed such an education, based as it was on the study of the revered Chinese classics, as a threat to their religious and cultural identities. This fear was intensified whenever the Han officials intensified the promotion of classical Chinese education in order to encourage assimilation or acculturation. Recurrent throughout Chinese history are such official campaigns. Examples include the so-called "barbarian schools," or fanxue, established during the Tang to promote education in Chinese classics for the Muslim "barbarians." In the 19th century, after the widespread Muslim rebellions in Gansu and Yunnan, officials built educational institutions, sometimes funded by confiscated Muslim properties, in order to promote the assimilation of Muslims as a protection against any future such rebellions. ${ }^{9}$

The second type of Muslim education is, of course, religious. Before the Ming Dynasty, the mosque provided informal religious education. Starting from the mid-Ming, a more rigidly organized form of religious education, jingtang jiaоyu (scripture hall education), emerged. ${ }^{10}$ This new institution developed as cultural assimilation increasingly became a threat to faith. ${ }^{11}$ Most of these "scripture halls" were attached to mosques and employed full-time professional instructors. Over time, this system developed a long line of famous instructors, and three main centers of instruction in Shaanxi, Shandong and Yunnan. It included a systematic and rigid curriculum which was based on "thirteen scriptures" covering Arabic grammar and literature, tafsir (Quranic interpretation), hadiths (prophet Muhammed's deeds and sayings), balagh (rhetoric), 'Ilm al-Kalām (theology), figh (Islamic jurisprudence), logic and Islamic philosophy. ${ }^{12}$ While the teaching material was mostly in Arabic and Persian, a distinct form of Chinese, called jingtangyu (scripture hall language), was the language of instruction. The scripture halls regularly provided religious education on two levels. The lower level, called the "Elementary Academy," provided children of the community with instruction in elementary Arabic and basic religious knowledge. The higher level, known as the "High Academy,"

8. Zhou Chuanbin, op. cit., p. 40 .

9. Yang Zhaojun, Yunnan huizu shi, p. 196-198.

10. For an extensive treatment of the founder of "scripture hall education," Hu Dengzhou, and the Chinese Islamic educational network during the Ming, see Zvi Ben-Dor Benite's chapter titled "The Islamic Educational Network" in his The Dao of Muhammad.

11. The assimilation was caused by both having been long-time residents in China as well as government policy. The Ming government prohibited foreign clothes, language, and surnames and banned marriage between foreigners.

12. Zhou Chuanbin, op. cit., p. 9. 
provided training for religious professionals. Students of the High Academy, called manla or hailifan, studied full-time and enjoyed free food and board. It usually took around 10 years to complete the High Academy, although there was no set length. ${ }^{13}$ Since each mosque tended to hire only one teacher (called a kaixue ahong), students had to visit many mosques, some far away, in order to complete the curriculum. ${ }^{14}$ Because of the stability of the scripture hall institutions from the Ming on, Chinese Islam developed its own canon of philosophy, ethics, and theology. As the pillar for sustaining the faith of the community, those educated in this system gradually assumed leadership roles within China's hui community, replacing the hereditary religious leaders. ${ }^{15}$

These two types of education, Chinese and Islamic, contributed to the construction of hui ethnicity. On one hand, Chinese education, whether taken voluntarily or not, promoted identification with the state and mainstream Chinese culture. On the other hand, scripture hall education, while limited in its scale, provided a religious orientation which formed the foundation for the hui culture.

As early as the middle of the Qing dynasty, a new type of Muslim educational institution that provided both Islamic and Chinese education emerged. Some were called jingshu yixue, or "school for Islamic scriptures and Chinese classics." Other schools went by names such as qingzhen xuetang (Islamic academy) or jingru xiaoxue (Quran-Confucian elementary school). These institutions provided 2-3 years of education in both the Chinese classics and Arabic and Islamic knowledge. ${ }^{16}$ In 1883, for example, a mosque in Haiyang County of Henan established a school for thirty students in which both Arabic and Chinese were taught. ${ }^{17}$

In the early 20th century, these "schools for Islamic scriptures and Chinese classics" underwent significant changes. The most important change took place in the curriculum, where the portion formerly solely devoted to the Chinese classics was expanded to include general subjects. For example, the Dongguan Mosque's school in Luoyang, established in 1822, changed its name to Elementary Academy in the early 1910s and included Chinese, mathematics, and current events in the curriculum. ${ }^{18}$

Muslim educational reform in the early 20th century was a product of both official campaigns and efforts by reformers within the community. After the late Qing government promoted the new-style schools, a large number of Muslim

13. Ibid., p. 75 .

14. Ibid.

15. Hu Yunsheng, op. cit., p. 148-149.

16. Zhou Chuanbin, op. cit., p. 104.

17. Li Dechang, "Zhoukou huizu jiaoyu de lishi xianzhuang yu fazhan duice," p. 49.

18. Hu Yunsheng, op. cit., p. 177. 
schools emerged. However, since the government did not provide sufficient funding, most of these new schools were funded by Muslim communities themselves. Private initiatives sometimes were motivated by the desire to modernize the community and sometimes in response to official pressure. For example, around 1931, Feng Yuxiang governed Henan and launched a campaign to turn temples (including mosques) into schools. In response, Muslims built schools inside the mosques in order to keep their mosques. ${ }^{19}$ Unlike traditional mosque sponsorship, the new-style Muslim educational institutions were sometimes sponsored by the government, sometimes by private Muslims, and sometimes jointly sponsored by the government and Muslim individuals. Often, the same institutions would move between all three kinds of sponsorship during the course of their existence.

Since most of these schools received at least part of their funding from Muslim individuals, these individuals had a substantial influence over the operation of the school. As a result, these schools maintained their Islamic characteristics, including training in Arabic, and in basic Islamic doctrine. Many exclusively recruited Muslim students. Such autonomy, however, would be lost when financial difficulties or government intervention made the schools'sponsorship solely governmental. When the Muslims schools merged with governmentsponsored schools their Islamic character was lost. Scholars have recorded examples of such merging in Henan, Heilongjiang, and other provinces ${ }^{20}$ Over all, efforts to promote new-style education for Muslims faced great difficulties, as a result of the political and economic turmoil that plagued the country during this period. For the most part, Chinese Muslim communities remained poor and isolated and Muslim children had limited access to education of any kind.

Among the many difficulties these new Muslim schools faced, a recurrent problem was the lack of qualified teachers trained in both secular subjects and religious learning. Responding to this challenge, a new-style High Academy of scripture hall education emerged in the early 20th century. They were no longer called the High Academy but took a modern name, shifan, or teachers academy. The purpose of this modern version of the "High Academy" was to cultivate Imams and teachers within the framework of the new curriculum. ${ }^{21}$ These teachers would be capable of teaching Chinese classics and general subjects in addition to religious subjects. The earliest Muslim teacher training institution was established by Imam Wang Kuan and his student Imam Da Pusheng in

19. Ibid., p. 180.

20. Ibid., p. 178; Also see Gu Wenshuang et al., "Helongjiang xinshi jiaoyu shulue."

21. The Chinese term for imam is ahong, a word that came from the Persian word "Akhund." 
Beijing in $1908 .{ }^{22}$ Like other new-style Muslim elementary schools, many of these new-style teachers academies were forced out of existence by extreme financial difficulties. ${ }^{23}$ Out of all these new schools, the Chengda Teachers Academy was the most successful and influential. The following sections will use the case of Chengda to illustrate the key figures involved in Muslim educational reform, the purpose and content of the reform, as well as how it was affected by the sense of an ethnic identity.

\section{Replacing the Scripture Hall with the Teachers Academy}

In the early 1920s, several influential Muslims in Jinan of Shandong province became interested in building a post-elementary school that would educate Muslims qualified to be teachers in the modern Muslim schools. Tang Kesan, then an official at the prefecture of Jinan, came from a Shandong Muslim family that had been successful for generations in the civil service examination system. Tang himself had been involved in the founding of Chinese Islamic Progressive Association (CIPA) in 1912 (the first country-wide Muslim association) when he was a member of the first National Assembly of the Republic. In the same year he built a Muslim elementary school in his hometown in Zouxian, Shandong. ${ }^{24}$ Two other Muslims involved were Mu Huating and Fa Jingxuan. Mu Huating, whose family owned the property on which the school would be established, was a retired military officer who had performed hajj around $1920 .{ }^{25}$ Seeing the dissolution of the Ottoman Empire and the nationalist secularist reforms in Turkey strengthened his desire to adopt similar reform efforts and pull Chinese Muslims out of the poor conditions similar to those he had witnessed in the Middle East. Mu also found Chinese Muslims less educated than Muslims in other countries and wanted to develop education for Chinese Muslims. ${ }^{26} \mathrm{Fa}$ Jingxuan was a local businessman and at the same time a self-taught Muslim scholar who loved works by Liu Zhi, an author of the famous Han Kitab, Islamic religious texts written in classical Chinese during the 17 th century. ${ }^{27}$

In 1922, Mu Huating went to Tianjin and Beijing to seek an Imam who could help with the building of the new school. He found Imam Ma Songting, who had studied with prominent reformers Imam Zhang Ziwen and Imam Da Pusheng, both founding members of CIPA (Imam Da Pusheng was Imam Wang Kuan's

22. Qiu Shusen (ed.), Zhongguo huizu shi, vol. 2, p. 701.

23. Zhou Chuanbin, op. cit., p. 128.

24. Ma Bozhong, "Tang Kesan yu chengda shifan,” p. 26.

25. Ma Bozhong, "Huizu minren Mu Huating," p. 160.

26. Ibid., p. 161.

27. Ma Bozhong, "Fa Jingxuan yu chengda shifan,” p. 204. 
student and had co-founded with Imam Wang Kuan the first new-style Muslim schools in Beijing). Ma Songting liked the idea of building a new-style school to train leaders of the Muslim community. He left his position as the Imam at the Xidan Mosque in Beijing and came to Jinan with four of his students (halifan).

Between 1922 and 1925, they worked on preparing the community in Jinan for a new-style school for Muslim education. In the small mosque built by $\mathrm{Mu}$ Huating, the Imam gave sermons, and offered night classes to elders and children. In these night classes both Arabic and Chinese were taught. Free classes were offered for poor people and women. ${ }^{28}$ By these measures, the small mosque, and its emphasis on improving the lot of Muslim community through education, increased its influence in Jinan.

The reformers then started to recruit students for a new-style teachers academy. Fa Jingxuan, who enjoyed a good reputation among the locals, took on the responsibility of recruiting local students. Initially, few parents he spoke to were willing to let their children learn to read Chinese, seeing this kind of new-style education as heterodoxy. ${ }^{29}$ But after much persistence and persuasion, stemming largely from the efforts of the Imam himself, a few local Muslim families agreed to enroll their children. Thus, in 1925, the Chengda Teachers Academy was formally founded, with Tang Kesan as the headmaster and Ma Songting in charge of running its daily affairs. Several local students, plus the students brought by Ma Songting from Beijing, formed the first class of Chengda. Few of the first group of a dozen students, however, had the required elementary-school education originally hoped for by the school's founders. ${ }^{30}$

In 1927, with a few more donors joining the board, Chengda expanded and several graduates of Beijing University were hired as teachers. In this year, Chengda adopted a six-year system, a standard for teachers colleges at the time. ${ }^{31}$ Compared with the "one teacher-several students" model in traditional scripture hall education, Chengda instituted classes and grades. While many of the rules of the school were similar to non-Muslim schools, students at Chengda were treated in the same manner as halifan (religious students) had been at the traditional scripture hall. For example, they were all required to observe daily prayers and Ramadan. ${ }^{32}$

Chengda made three key changes to the traditional scripture hall education: adopting the Chinese language, general education, and emphasizing the expected

\footnotetext{
28. Ma Bozhong, ibid., 207. For a detailed study of the Han Kitab, see Benite, The Dao of Muhammad.

29. Ibid.

30. Zhou Zhongren, "Jinan chengda shifan," p. 5.

31. Ma Bozhong, "Chengda shifan: musilin jiaoyu de dianfan."

32. Zhou Zhongren, op. cit., p. 4.
} 
roles its graduates would play. The first is language. Since most Chinese Muslims could no longer read Arabic or Persian it usually took students of the Scripture Hall many years to master these languages. Thus the refusal to use the Chinese language in religious education had increasingly become an obstacle. Imam Pang Shiqian, who would later be recruited by Chengda commented in a 1929 article: "By placing such an emphasis on the study of Arabic and Persian language and grammar, and without using the national language (guowen), the religious doctrines themselves are being increasingly neglected." ${ }^{33}$ Pang raised an issue that many reformers had seen. In order for Chinese Islam to grow or even to survive, using the Chinese language as a carrier for religious texts (including the Quran) was inevitable. In a way, the Chengda founders became the 20th century successors of the Han Kitab generation of Muslim integrationists. The founders were admirers of Liu Zhi and were well-read in his works. ${ }^{34}$ Like Liu Zhi, they were interested in promoting the full integration of Muslims into Chinese society. This principle meant that Muslims should engage directly with Chinese society, and enlighten the Chinese with Islam by adopting the Chinese language as the carrier of religious texts.

Traditionally, many Muslims had viewed with suspicion those who studied the Chinese classics, believing that Chinese learning was a threat to Islam. Muslims were particularly suspicious of those who were well-enough versed in the Chinese classics to pass the civil service exams and gain entry to the bureaucracy. This was reflected in the saying "those Muslims whose official rank reached the third pin are necessarily anti-Islam (guan dao sanpin bi fanjiao)." 35 Muslims generally did not send their children to Chinese schools, in part because of the inconveniences posed by dietary restrictions but also because of a fear of assimilation. Under the old-style mosque-based education, children only studied religious texts, and only in Middle Eastern languages. This unwillingness to study Chinese classics, Muslim educational reformers believed, had produced the backwardness of the Muslim communities by limiting Muslims'ability to seek economic and other opportunities in Chinese society. In the minds of the reformers, Chinese Muslims had lived in a closed world for too long, and this self-imposed marginalization had caused the Chinese Muslim community to lag behind other groups in Chinese society. To remedy this marginalization, it

33. Pang Shiqian, "Quanguo qingzhensi hailifa jiaoyu ganliang chuyi."

34. Wang Mengyang, "Yige you zhongguo huimin ziban de beiping chengda shifan xuexiao shimo jishi," Chengde dacai, p. 12.

35. Du Zhuoya \& Wang Hongyan, "Ningxia huizu nonghu he hanzu huizu nonghu de shouru chayi chengyin fenxi," p. 44. 
was seen as necessary that Muslims learn written Chinese and participate in full in Chinese life.

The second aspect of Chengda's reform was to provide a general education instead of simply a religious education for its students. In terms of curriculum, Chengda expanded on the Scripture Hall's traditional exclusive focus on theology, and incorporated education in secular subjects. ${ }^{36}$ Persian was no longer taught. ${ }^{37}$ Arabic, Chinese, and Islamic theology were taught in all six years. Some of these theology classes were taught in Chinese and others in Arabic. Fa Jingxuan taught theology classes in Chinese and used books from Han Kitab, including Liu Zhi's Tianfang Dianli and Tianfang Xingli. ${ }^{38}$ In the first three years the students would also study history, geography, mathematics, physics, chemistry, and biology; during the last three years they would focus on educational methods, school administration, accounting, and so on. ${ }^{39}$ Martial arts were also taught. ${ }^{40}$

This new emphasis on secular subjects reflected trends in both China and the broader Islamic world. In the Islamic world, responding to the growing dominance of Western countries in the late 19th century and early 20th centuries, many in the Islamic world advocated adopting Western institutions and ideas in order to catch up with the West. Promoting a modern-style education, instituting civil law codes based on Western models, and advocating nationalism and decolonization were some of the most important themes in these reform efforts. ${ }^{41}$ Print culture and transportation were instrumental in linking Chinese Muslims to this broader modernizing Islamic movement. Arabic books on reformist thinking in such fields as politics, constitutional government, international affairs, economics, and civil law were imported..$^{42}$ Besides these influences, travel to the Middle East exposed Muslims, especially imams fluent in Arabic or Turkish, to Muslim modernist ideas. The founders of Chengda were clearly influenced by this modernizing movement in the broader Islamic world.

The third aspect involves citizenship education. Interested in generally promoting Muslim identification with the Chinese nation-state, the Chengda leaders made "patriotism education" an important part of the curriculum.

36. Zhou Zhongren, op. cit., p. 4.

37. Joseph Fletcher and Zvi Ben-Dor Benite have discussed the effort by Muslims during the period to adopt Arabic-style calligraphy and the Arabic language which they perceived as more orthodox than Persian.

38. Ma Bozhong, "Fa Jingxuan yu chengda shifan," p. 208.

39. Zhou Zhongren, op. cit., p. 4.

40. Ma Bozhong, op . cit., p. 205.

41. See Kurzman, Modernist Islam.

42. Zhang Ziwen, "Shuo wenzi zhi zunzhong." 
Chengda's de facto headmaster, Imam Ma Songting, wrote in 1936 that traditional education did not educate students with "spirit of the time (shidai jingshen) or "notion of the country (guojia yishi)" and caused the Muslim community's isolation from Chinese society. ${ }^{43}$

Interestingly, such an emphasis on teaching secular subjects and training Muslims to be good citizens of China was shared by leaders of another Islamic movement in Northwest China, the Ikhwani movement. Originally inspired by teachings of 'Abd al-Wahhab, the Ikhwan in the 1930s dissociated itself from 'Abd al-Wahhab and made efforts to appear politically reliable. ${ }^{44}$ One notable leader of the movement, Imam Hu Songshan, actively supported the teaching of Chinese, modern subjects, and patriotism in Muslim schools. ${ }^{45}$

\section{Resettlement in Beijing (1928-1937): The Flourishing of Chengda with Political Supports}

In May 1928, Japanese forces took practical control over Jinan in the name of protecting Japanese citizens and property in the face of the advance into Northern China by the army of the newly established Nationalist Party government in Nanjing. The city was in a chaotic situation and schools could no longer operate. ${ }^{46}$ Tang Kesan and Ma Songting went to Beijing to seek help from the powerful Muslim warlord Ma Fuxiang, who had been appointed as the deputy director of the Nationalist government's Mongolian-Tibetan Committee. ${ }^{47}$ Ma agreed to provide financial support and offered a large property of his in the Dongsi Mosque in Beijing as a new Chengda location. ${ }^{48}$ The board then decided that Chengda would move to Beijing. At a farewell party given at a mosque in Jinan, Fa Jingxuan gave a speech comparing this move to the Prophet Muhammad's hijra. ${ }^{49}$ After the party, teachers and students left Jinan in the rain in ten rickshaws. To avoid harassment by the Japanese, they all wore armbands that pretended to show that they were members of the Red Swastika charity organization, and went to a train station in a nearby town to catch a train to Tianjin. ${ }^{50}$

43. Ma Songting, "Zhonguo huijiao yu Chengda shifan xuexiao."

44. Lipman, Familiar Strangers, p. 208-209.

45. Ibid., p. 210.

46. Ma Bozhong, "Chengda shifan: musilin jiaoyu de dianfan."

47. Ibid.

48. Ibid.

49. Ma Bozhong, "Fa Jingxuan yu chengda shifan," p. 209.

50. Ma Bozhong, "Huizu minren mu huating," p. 167. 
In the summer of 1928 , the Nationalist Party successfully defeated the warlord-controlled government in Beijing and, at least in name, reunified China under a new central government in Nanjing. Although the political climate was still plagued by struggles among the remaining warlords, and between the central government and the aggressions by foreign powers, notably Japan and Russia, and the Nationalist Party's obsession with curbing the growing Communist Party, nevertheless things gradually returned to normal as the Nationalist government returned law and order to many parts of the country and a relatively liberal and reform-minded environment provided a friendly environment for Chengda to grow. Recruiting qualified students and teachers became much easier.

Like many other new-style Muslim schools, Chengda might have ended its existence due to financial difficulties and political turmoil at this time. Financial support from a politically powerful figure (Ma Fuxiang in this case), however, prevented this and would continue to be important for the school's future development. Because of the strength of the Muslim warlords in the northwest, and because of the sensitivity of religious and ethnic issues, the Nationalist government in the 1930s (and in the 1940s as well) adopted a policy of co-opting these Muslim warlords. Among them Ma Fuxiang was particularly trusted by Chiang Kai-shek. Because of his financial power and political connections, Ma remained the guardian angel for Chengda until his death in 1933.

Ma Fuxiang had been promoting the Muslim cause in the Northwest during the 1920s. During the warlord period (1917-1927), most parts of China were caught in the middle of wars among various warlords which of course greatly impeded any of these reform efforts. Some scholars have argued, however, that the Muslim warlords in the Northwest, who increased their power during this period, played a "special role" in the Muslim communities through their promotion of industry, commerce and education. ${ }^{51}$ During this period, Ma Fuxiang, based in Ningxia, played the most significant role. In 1918, he had established the Office for Promoting Mongolian and Muslim Education in Ningxia. At the same time, he sponsored dozens of Islamic elementary schools (Qingzhen xiaoxue) in which Arabic was taught along with the general curriculum. ${ }^{52}$ In 1919 he donated a sum of money to enable Gansu youths to study outside Gansu or abroad. ${ }^{53}$ In the 1920s, he sponsored the printing of a number of Chinese texts on Islamic doctrines - the Han Kitab. ${ }^{54}$ Other than Ma Fuxiang, powerful Muslim warlords

51. Xu Xianlong, Zhuma junfa jituan yu xibei musilin shehui, p. 7.

52. Ding Mingjun, "Ma Fuxing yu xiandai huiru duihua," p. 27.

53. Ma Bozhong, "Yuehua chuangshiren liren zhubian bianji shengping jianjie," p. 98.

54. Ding Mingjun, "Ma Fuxiang minzu sixiang tanxi," p. 27. For the Muslim Han Kitab literature, see Benite, The Dao of Muhammad. 
such as Ma Qi and Ma Bufang in Qinghai also promoted modern education through establishing schools such as the Ninghai Islamic School, where religious texts were taught in addition to the regular curriculum, and Friday was the day off. While these Muslim warlords clearly engaged in these projects in order to strengthen their own base of influence, they were also evidently believers in the role of education in modernizing the Muslim communities and integrating the Muslim population into the Chinese nation.

After the founding of the Nanjing government, Ma continued to promote reform projects for Muslim communities. In 1927, he established the Chinese Islamic General Association in Shanghai. In 1928, Ma Fuxiang established, with Sun Shengwu, a Muslim middle school in Ox Street. ${ }^{55}$ He gained the trust of the Nationalist government in part because of a pledge of loyalty to the central government and in part because of his strong commitment to promoting the integration of Muslims into the Chinese nation. Many of his actions and words show his commitment to help integrate ethnic minorities into the nationstate through a modern education that both taught written Chinese and also cultivated patriotism. The Nationalist government put Ma Fuxiang in charge of the Mongolian-Tibetan Committee for the purpose of integrating not only Muslims, but also other boarder peoples like Mongolians and Tibetans into the nation-state. In 1928, Ma became a member of the Military Committee of the Nationalist Government, and head of the Mongolian-Tibetan Committee. In 1929, he compiled a textbook (on patriotism and other topics) for a seminar he taught to Mongolian and Tibetan military officers. ${ }^{56}$ After becoming involved in the Mongolian-Tibetan Committee, he also continued to invest in modern Muslim schools everywhere, though Chengda was one of his favorites. Between 1929 and his death in 1933, Ma provided one hundred yuan per month for the publication of Yuehua, the school's influential journal, discussed later in this article. In 1931, he donated 300,000 shares of a textile factory as an endowment for four Muslim schools including Chengda. In addition to providing funding himself, Ma Fuxiang used his position as the head of the Mongolian-Tibetan Committee to obtain 700 yuan a month of official funding for Chengda. ${ }^{57}$ After his death, his son, Ma Hongkui, became the board director of Chengda and continued to provide funding for the school.

In Beijing, Chengda also established ties with other Muslim officials. Two officials and founders of CIPA in 1912, Hou Songquan and Ma Linyi, both became board members. Ma Linyi was the first head of CIPA in 1912. As

55. Ding Mingjun, ibid.

56. Ma Bozhong, "Yuehua chuangshiren liren zhubian bianji shengping jianjie," p. 99.

57. Ding Mingjun, "Ma Fuxiang minzu sixiang tanxi," p. 28. 
mentioned in the last chapter, Ma Linyi had been a Qing official, joined Sun Yat-Sen's Revolutionary Alliance in Japan and had close relations with Sun Yatsen. He continued to hold high-level positions in the Republican government, either controlled by the warlords or by the Nationalists. In the 1910's, he was the head of the Department of Education in Gansu and promoted modern Muslim education there, building nearly three hundred schools for Muslims. In 1920 he became deputy Director of the Ministry of Education. ${ }^{58}$ These high officials provided both financial and other support to Chengda. The fact that these Muslims had high political status in the modern Chinese nation-state was consistent with the reformers'desire to claim their rightful place in the Chinese nation-state and encouraged them to continue that pursuit.

Chengda flourished. The school expanded and the student body grew. By 1930 the school expanded from a dozen students to over a hundred. ${ }^{59}$ The first class graduated in 1932, after eight years'study. ${ }^{60}$ This graduation was widely publicized and received considerable attention from both the non-Muslim as well as the Muslim community. In the 1930s the school sent several groups of students to study at Al-Azhar University in Cairo. In 1932, Ma Songting visited the king of Egypt and the president of Al-Azhar and brought back over four hundred books donated by the king and Al-Azhar University as well as two professors from Al-Azhar. ${ }^{61}$ To promote the translation of religious texts into Chinese, starting in 1929, Ma Songting organized Chengda students and faculty to translate the Quran. ${ }^{62}$

After several years of experimenting, shortly after settling in Beijing, Ma Songting's ideas about what Chengda education should focus on became clearer. He decided that Chengda's students should become capable of being, in his phrase, "three heads at once": heads of mosques, heads of schools, and heads of CIPA branches. This differed dramatically from the kind of goals envisaged by the traditional scripture hall. Ma decided that leaders of Muslim communities should also be able to improve general education for the community and promote social and political activism.

Chengda was not the only Muslim teacher training institution. Other Muslim teacher training institution at the time included the Shanghai Islamic Teachers Academy, established in 1928 by Imam Ha Decheng and Imam Da Pusheng (with Ma Fuxiang as the main founder), ${ }^{63}$ the Mingde High School in Yunnan,

58. Ma Bozhong, "Yuehua chuangshiren liren zhubian bianji shengping jianjie," p. 102.

59. Ma Bozhong, "Chengda shifan: musilin jiaoyu de dianfan."

60. Ma Bozhong, "Fa Jingxuan yu chengda shifan," p. 208.

61. Ma Bozhong, "Chengda shifan: musilin jiaoyu de dianfan."

62. Ibid.

63. Ding Mingjun, "Ma Fuxiang minzu sixiang tanxi," p. 28. 
established in 1929, the Wanxian Islamic Teachers Academy in Sichuan, established in 1928, the Chinese-Arabic Teachers Academy in Wuzhong, Ningxia, and Yunting Middle School, established by Ma Hongkui in 1934. Chengda's central location and its powerful patrons, however, made it the most successful new-style Muslim educational institution.

\section{Chengda's Promotion of Patriotism through Yuehua Magazine}

The Muslim educational reform movement paid special attention to Muslims'place in the new nation-state. In the fall of 1929, Chengda started to issue the Yuehua magazine. Issued three times a month, and widely circulated, Yuehua became an effective tool in promoting the Chengda vision of Muslim modernization. In the first issue, published on November 5, 1929, six goals were listed:

1. to carry out Islamic doctrines consistent with modern (xiandai) trends;

2. to introduce news about Muslims (huimin) in other parts of the world;

3. to improve awareness of Muslims in China (zhongguo huimin) and improve their status;

4. to explain the misunderstandings between the new and old Muslim sects ;

5. to strengthen the sense of country (guojia guannian) among Muslims in China ;

6. to promote education and a better livelihood for Muslims in China. ${ }^{64}$

The Chengda Publishing House was established in 1933 and printed numerous Chinese and Arabic texts of Arab and Islamic studies. Aside from Yuehua, the Chengda-produced journals included Chengshi yuekan, managed by the Student Union of Chengda. In 1929 Chengda sponsored the Chinese Islamic Students Association. ${ }^{65}$ This association helped promote interactions between Chengda students and Muslim college students who had not necessarily received religious training. This not only gave these students more of a sense of their religion, but also exposed the Chengda students to modern ideas and trends.

From its founding, as I have suggested, a distinctive and central goal of Chengda's educational program was to promote a sense of country (guojia yishi). Their arguments had a number of strands. Many Muslims at that time did not identify themselves as Chinese, but looked toward Turkey and the Arabic world as their real homeland. Chengda sought to convince these Muslims that since they had lived in China for many generations so China was, obviously enough, their country (guojia), and they should think of their sense of religious

64. Anonymous, Yuehua 1, no. 1 (November 5, 1929), 1.

65. Anonymous, "Yisilan xueyouhui diyici dahui jishi." 
identity as something quite separate from their political identity as Chinese citizens. Religion was about faith, whereas love of country was concerned with the physical survival of a people, and was independent of religion. They also made the case that identifying with China was a temporary measure for Chinese Muslims until a pan-Islamic empire was re-established. In an ideal world, Muslims all over the world would be united by their religion, and national borders (guojie) and ethnic (zhongzu) differences would not matter. But since that was not going to happen immediately, the second best thing would be to unite Chinese Muslims, since the religion could only prosper when China was strong. In a world where the strong oppress the weak, and only the fittest survive, many countries had lost their statehood (wangguo). The five races in China therefore needed to work together to save China. ${ }^{66} \mathrm{~A}$ conception of the nation, based on the ideal of a "Republic of Five Nationalities" would empower Muslims. In this sense, the Islamic revival in China could merge with the Chinese national revival project. Furthermore, Yuehua argued that patriotism was required by religion. This idea was promoted by clergymen like Wang Jingzhai, who, in a famous article, looked toward religious authorities for doctrines that said Muslims should love their country. One passage Wang cited in this article, and which was adopted by later Muslim reformers throughout the century, noted that the Prophet had once said that loving one's country was required by faith. ${ }^{67}$ Wang's article became influential in the cause of promoting patriotism among Muslims because Wang and his sources represented a religious authority that could not be easily disputed.

Chengda's influence went beyond its campus. Yuehua was issued frequently and had a wide readership among Muslims. Other Chengda journals such as Chengda Wenhui, were also influential. The Chengda publishing house published translated Arabic texts, reprinted Han Kitab, and published the first Chinese version of the Quran translated by a Muslim, Imam Wang Jingzhai. Through these publications, Chengda promulgated both religious and secular visions held by Chengda faculty and students among the reading Muslim public in China.

Chengda's role in promoting Muslim integration is an example of convergence of interest between Hui Muslim elites and the Chinese state. In addition, Chengda's success benefited from the stable political situation made possible by Nationalist Party's consolidation of power in China. One important reason for its success was that the Nationalist leaders themselves sought close relations with high level Muslim officials, who in turn influenced Chengda

66. For an expression of such ideas, see Liu Zhou, "Zhongguo huimin yingyou guojia zhi guannian."

67. Wang Jingzhai, "Jinshou huijiao yu aihu guojia." 
with their personal and state interests. Thus the school also functioned as an intermediary between the state and the Muslim public.

\section{Chengda in the Debate on Muslim Nationality}

In the late 1920s and early 1930s, a debate went on among Chinese politicians and intellectuals about whether all Muslims in China form a huizu, or a Muslim nation/race. The government officials, fearing that Muslims would demand greater political representation, insisted that only the Uyghur should be considered the huizu, while other Muslims were simply ethnic Han Chinese with Islamic faith. As they had been in the late Qing and early Republic, Muslims were divided on this issue. Some, worried that being seen as a separate nationality would hinder their efforts to fit into the Chinese nation, agreed with the government that only the Uyghur were the huizu. More Muslim intellectuals, however, believed that all Muslims, including the Chinese-speaking Muslims, were huizu, or the "Hui nation." For them, being labeled as a separate nation meant greater representation in the political system. Chengda and Yuehua belonged to the second group. By insisting that all Muslims in China were huizu, they also wanted to promote unity among all Muslims, including the Uyghur. They used Sun Yat-sen's definition of nation $(z u)$ to argue their case. The third issue of Yuehua published the following comments by Sun Yat-sen,

In general, people who worship the same god or believe in the same ancestor, can form a nation (minzu). The strength of religion in making nations is enormous: take Arabic and Jewish countries ( $\mathrm{guo}$ ). The countries themselves have long disappeared, but the Arabs and the Jews survive. This is exactly because they each had their religion. ${ }^{68}$

Sun's words couldn't be clearer: shared faith alone provides the basis for the formation of an ethnic group. By reminding Muslims that they belonged to a larger entity the editors sought to promote unity among Muslims in China. The first article on this issue of Yuehua dealt with the very problem of disunity in Muslim countries. This article, written by "Xingwu," sought to find the reason for the decline of Islam and the answer was disunity. The author lamented that Muslims, holders of the true religion, had been enslaved by "the white people who believed in other religions" (yijiao de bairen). The biggest reason for such a situation was disagreement among different sects. The author then raised two examples from among Muslim countries to make this point. Turkey was a positive example of a Muslim country that, through the unity of its people, had succeeded in gaining independence and had modernized. The negative example

68. Anonymous, "Dangyi xiehua." 
was Afghanistan, which had failed because of a lack of such unity. The author then said that Chinese Muslims were divided between the two kinds of people. One kind were the conservatives who focused solely on religion and remained oblivious of things going on in the country and in the world. The other type were the ones who leaned toward new things and essentially disregarded their religion. As a result of this split, Islam had not prospered in China and non-Muslims knew little about their religion. At the end of the article, the author called on the two sides to correct their weaknesses, unite their thinking (sixiang tongyi), and get rid of divisions in order for "the truth of Islam to shed its light." 69

The influence of pan-Islamic sentiments also led Chengda to argue that all Muslims were the same nation. Its contacts with the Islamic world through educational exchanges introduced trends in the Islamic world both in its classrooms and through its publications. Through these contacts, Chengda came to see the Chinese Islamic revival movement as part of a global Islamic revival. Articles in Yuehua often compared the situation of Muslim communities in China with those in the rest of the Islamic world. This comparison tended to lead to the conclusion that Muslims in China were behind Muslims in other parts of the world and that it was time to devote energy to reviving Islam in China. When a Chengda student in Egypt wrote and published an article in Yuehua about the Islamic youth movement he had learned from people from Western Asia, ${ }^{70}$ Yuehua responded by publishing a series of articles discussing how Chinese Muslim youths should respond to such a movement. In the period 1933-1934, the Chengda journals published numerous student opinions advocating panIslamic sentiments. For the most part, though, such pan-Islamic sentiments were not specifically political in character, and focused instead on the need of Islam to modernize. As such, Chengda leaders did not view their development as threatening to the Chinese state.

These efforts did however alarm the Nationalist government. Some officials believed that the insistence that all Chinese Muslims in China belong to the Hui in the "Republic of Five Nationalities" implied much greater political representation than what the Nationalist state was willing to grant, and would hinder the state's assimilationist goals. Furthermore, they were worried that this definition, and the Chengda students'expressed interest in pan-Islamism, would be exploited by Japan in its efforts to co-opt Chinese Muslims..

As a result, in 1934, Ma Hongkui, at the time the board director of Chengda and Chairman of Ningxia Province, published an open letter in the Dagongbao, he expressed uneasiness over Chengda's pan-Islamic positions, saying that

69. Xin Wu, "Huijiao buzhen de genben renshi."

70. Anonymous, "Yisilan qingnian yundong". 
Chengda's display of an Islamic star-and-moon flag, tended to present Chengda as a kind of embassy, and was "a big mistake." He also directly criticized Chengda's position that all Muslims belonged to the same minzu. He said,

[...] religion is not race (zhongzu). Although Islam originated in Arabia, believers are all over the world. One cannot say that all believers of Islam are of the same people. Everyone knows this. We are members of zhonghua minzu, we are citizens of China despite our faith in Islam. ${ }^{71}$

Ma opposed the argument that all Muslims in China were huizu for two reasons. First, his opposition was shared by some Muslim reformers who thought labeling Muslims as a separate $z u$ would hinder the goal of incorporating Muslims into the Chinese nation. Second, he understood the Nationalist government's concern that calling all Muslims a nationality could cause pan-Islamic sentiments which could be exploited by Japan. Ma published this letter out of concern for his own political career in the Chinese state. He wrote,

Currently I have important military and political responsibilities and thus I do not dare to agree [with such practice]. Yesterday I sent a letter to headmaster Tang Kesan, seriously stating that I ask him to educate students according to the school's original mission and with Arabic and Chinese religious texts, to stop activities outside [Chengda], and abolish all publications other than teaching-related material. [If Chengda] corrects past mistakes, I will continue to take the responsibility [of being director of the board]... Otherwise [I] will sever my relationship with the school... ${ }^{72}$

Apparently, Chengda's activism outside the campus had alarmed the government, and Ma Hongkui had to publish this open letter to show that he had nothing to do with such activities. On August 22, 1934, He Yaozu, a high-level official, sent a memo to Chiang Kai-shek and attached Ma Hongkui's letter. In the memo, he also expressed concern over pan-Islamic sentiments as well as over Japan's effort to exploit those sentiments. He wrote:

[The Japanese] believe that Muslims in China have strong religious faith but shallow national consciousness (guojia guannian) and as such have given them opportunities. [...] [A Japanese] first contacted Muslims in the Northeast and instigated several hundreds of Muslims who were influenced, and established daily newspapers and magazines for propaganda purposes. [Japan] also sent imams to promote [their ideas] in inner areas and its influence has gradually reached the Yangzi River areas... ${ }^{73}$

71. He Yaozu, [cable to Jiang Jieshi], August 22, 1934.

72. Ibid.

73. Ibid. 
He continues to argue that this Japanese effort to win over Chinese Muslims could benefit from Chinese Muslims'activities:

Muslims of our country had started a pan-Islamic movement since [1927]. This is the so-called new Islam. [Activists of this movement] have founded the Yuehua magazine and the Chengda Teachers College. Much of the messages in their propaganda and education violate the interest of the Nation (minzu). At that time the responsible person was Tang Kesan and others. Ma Yunting (another name for Ma Fuxiang) inevitably was being used. [The Chengda leaders'] activities included sending students to study in Egypt and hiring Egyptian teachers. [Chengda's] opinions say [those who believe in] Islam are [part of the] Muslim nation (huizu). [Some] even propose to awaken pan-Islamicism. They fell in the evil plot of the Japanese and established close contacts with Muslims in the Northeast... ${ }^{74}$

He Yaozu proposed that the way to deal with the problem would be two-fold. First, he believed that Muslims must be convinced that "nation (minzu) and religion should be separated." To achieve that goal, propaganda was needed to convince the Muslims that they were really Han Chinese who differed from other Han only in terms of religion. Second, he proposed using Muslim leaders to intensify efforts to indoctrinate Muslims with party doctrines. ${ }^{75}$

Despite this uneasiness on the part of the state concerning Chengda's activities, for the most part Chengda continued to operate as in the past. Responding to Ma Hongkui's letter, the headmaster Tang Kesan, published an announcement saying that Ma Songting's visit to Egypt was authorized by the school's board. ${ }^{76}$ Ma Hongkui, however, did eventually withdrew his support of Chengda which meant it had to find a new stable source for funding. Tang Kesan was at the time the Administrative Chief of the Mongolian-Tibetan Committee. Using his position, he managed to get the committee to give Chengda six hundred yuan per month. Then, in 1935, Tang Kesan and Ma Songting requested that the Nanjing government provide financial support which it agreed to do. ${ }^{77}$

Chengda's survival in this incident had much to do with the conflict with Japan and the state's consequent need to gain the cooperation of Muslim leaders. Because of Japan's occupation of Manchuria in 1932 and its increasingly clear intention to encroach on other parts of China, both the government and Muslim intellectuals came to see the Gansu-Ningxia-Qinghai region as a potential place for the government to retreat to in case of war. So starting from the early

74. Ibid.

75. Ibid.

76. Ma Bozhong, "Tang Kesan yu chengda shifan,” p. 28.

77. Wang Mengyang, "Yige you zhongguo huimin ziban de beiping chengda shifan xuexiao shimo jishi," p. 14. 
1930s, a movement of "developing the big Northwest" drew many people's attention to this hitherto neglected area. At the time, many among the Chinese intellectual community started to take an interest in the issues of Muslims and Islam and many started to study the society, religion, and other affairs of the Muslim communities. The most famous scholars were Fan Changjiang, who wrote about his trips to the Northwest, and the historical geographer $\mathrm{Gu}$ Jiegang, who took an interest in the history of Islam in China. Many realized the importance of Muslims in China's national defense and became interested in encouraging Muslims to participate in national salvation. Gu Jiegang, for example, commented in 1936,

Only since the serious oppression inflicted on us by Japan, we have started to pay attention to the borderlands. The attention paid to the borderlands made us pay attention to the most powerful Muslim communities in the Northwest. Because of that we started to communicate with Muslims. Only then did I start to admire their loyalty to their faith, the strength of their solidarity, and intrepidity of their work, and the hardship of their life. I thus know, warmly, that Muslims have heavy burden in the revival of the Chinese nation (zhonghua minzu). ${ }^{78}$

Such comments from Chinese intellectuals turned the traditional Han stereotypes about the Muslims as brave barbarians into admirable qualities that could be useful for the Chinese nation. The Nationalist state was torn at the time about how to deal with an institution like Chengda. On the one hand, it was concerned with strengthening control over the activities of the Chengda faculty and students. On the other, the need to use Chengda to promote the integration of Muslims and especially to carry out anti-Japanese propaganda in the northwest led the government to leave Chengda alone. As result, both the political and intellectual environment allowed Muslim institutions like Chengda to continue to thrive.

Between the time Ma Hongkui published his letter and the outbreak of the Sino-Japanese war, Chengda sent two more groups of students to Al-Azhar. In 1936, Ma visited Egypt for a second time to meet with the new king of Egypt, Faruk. In the same year, the Fuad library was established with Faruk's support. ${ }^{79}$ The library had thousands of books donated by the two Egyptian kings and others. throughout this periodChengda continued to graduate students who embodied the ideals of its founders: pious and patriotic Muslims.

78. Gu Jiegang, "Huijao de wenhua yundong."

79. Anonymous, "Chengda shifan tushuguan luocheng." 


\section{Chengda's Chinese Nationalism in the Anti-Japanese War and Its Nationalization (1937-1941)}

The national crisis gave Chengda an opportunity to shine as a patriotic Muslim institution. After the Marco Polo Bridge Incident of July 7, 1937, the Japanese expressed an interest in using the influence of Chengda for the purpose of establishing pro-Japanese Muslim organizations. ${ }^{80}$ They also offered to give Chengda 240,000 yuan. ${ }^{81}$ If Chengda's only concern had been to promote the religion it would have accepted the offer. But given its long emphasis on patriotism and religion, its leaders decided to move the school out of Beijing. Because Tang Kesan had relocated from Nanjing to Wuhan, Ma Songting traveled to Wuhan twice to meet him to discuss the move. During Ma's second visit to Wuhan in the summer of 1937, Bai Chongxi, a Muslim and the highest military commander in the Nationalist government's army, suggested that Chengda move to Guilin, Guangxi, his hometown. Accordingly, one morning in early January 1938, the Chengda faculty and students quietly left Beijing through two routes: one group taking a ship from Tianjin to Guangzhou, the other the land route through Zhenzhou to Wuhan. Both groups were met in Hengyang, Hunan, by a welcoming team from the Guilin Muslim community, and five military vehicles, arranged by Bai, were waiting to take them on the rest of their journey. ${ }^{82}$

Bai Chongxi's support was particularly important during this period. Like Ma Fuxiang, Bai took a personal interest in the Muslim modernization program, and the Chengda leadership saw close ties with him as crucial to the school's continued success. Ma Songting often visited Bai whenever he was in Guilin to report on the affairs of the school. ${ }^{83}$

While in Guilin, Chengda continued its participation in the dual cause of national salvation and religious revival. After arriving there, the students organized various activities to contribute to the war effort. In 1942, the Chinese Islamic National Salvation Association requested that Chengda send three persons to join the "Propaganda Team" in the Gansu-Ningxia-Qinghai areas. Chengda sent three faculty members including two who had studied in Egypt. ${ }^{84}$ At the same time, Chengda students carried out many religious activities. In Guilin, Chengda teachers and students reconverted a 500-person village to Islam. Residents of this village were related to Bai Chongxi but had lost their

80. Chang Qiming, "Bai Chongxi jiangjun yu chengda shifan xuexiao pianduan," in Chengde dacai, p. 181.

81. Ma Bozhong, "Chengda shifan: musilin jiaoyu de dianfan."

82. Chang Qiming, op. cit., p. 182.

83. Ibid, p. 186.

84. Ma Bozhong, "Tang Kesan yu chengda shifan,” p. 29. 
religious faith. Ma Songting and several students went to the village and lived there for three days and helped villagers realize they wanted to become Muslims again. ${ }^{85}$ Chengda then helped the village build an elementary school affiliated with Chengda as well as build a mosque for the village. Bai donated an inscribed board to be hung at the gate of the mosque on which he wrote Xingjiao jiuguo (Reviving Islam and Saving the Country). This slogan strongly reflected the relation between the state and Muslim reformers during the war. For the Muslim reformers, reviving the religion and saving the country were not conflicting goals, and for the Chinese state, the need to recruit Muslim reformers to help with "saving the country" made it tolerate, at least for the time being, the reformers'efforts to revive the religion.

In the end, the school's independence from the state did not last. In 1941 it was nationalized because of deep financial difficulties. The Ministry of Education appointed a new leadership and Ma Songting and Tang Kesan had to leave. Nationalization meant that Chengda started to admit non-Muslim students. While the religious classes were kept, it was no longer a pure Muslim school for Muslim students, though its Muslim character would be once again strengthened when it moved back to Beijing in 1945 following the end of the war with Japan. There it merged with Xibei Middle School to become the Huimin School. But in 1958, the Huimin School was abolished, bringing an end to an institution that had once been the flagship of a flourishing Muslim educational reform program. ${ }^{86}$ The current Chinese Quranic Academy, said to have been built on the precedent of Chengda, is a completely state-run organization to train Muslim clergy according to the visions of the communist government.

\section{Conclusion}

Driven by an impulse to mainstream Muslims in China, new-style Muslim schools in the early 20th century emphasized the learning of the written Chinese language and promoted citizenship education. As a result, these educational institutions became a main arena in which the Muslims in China were transformed into "Chinese Muslims."

Among the many Muslim reformist schools, Chengda was perhaps the most successful. It was long-lasting - founded in 1925, Chengda existed as a private institution until 1941. Chengda's students became influential religious, educational, and political figures. Chengda's teachers similarly were influential figures in Republican-era Muslim activism. Finally, Chengda's active

85. Chang Qiming, op.cit., p. 186.

86. Zhou Zhongren, "Jinan chengda shifan," p. 5-6. 
Mao Yufeng

publishing house produced influential reprints and journals that helped shape the development of Muslim activism during the time.

Chengda tried to maintain both a harmonized relationship between the religion and the nation, and a cooperative relationship with mainstream Chinese society and the Chinese state. At the same time, Chengda's pan-Islamic activities and its vision of Muslims'place in the Chinese nation often went beyond the comfort zone of the Chinese state and its eventual nationalization would mark the end of its half-century of Muslim educational reform. 


\section{BiBLIOGRAPHY}

Anonymous, “Chengda shifan tushuguan luocheng”成達師範圖書館落成, Yuehua 月 華 (8) 25, September 10, 1936, p. 9.

Anonymous, “Dangyi xiehua” 黨義擷華, Yuehua 月華 (1) 3, November 25, 1929, p. 1. Anonymous, “Yisilan qingnian yundong” 伊斯蘭青年運動, Yuehua 月華 (2) 3, January 25, 1930, p. 4.

Anonymous, “Yisilan xueyouhui diyici dahui jishi” 伊斯蘭學友會第一次大會紀實, Yuehua 月華 (1) 2, November 15, 1929, p. 2.

Atwill David, The Chinese Sultanate: Islam, Ethnicity, and the Panthay Rebellion in Southwest China, 1856-1873, Stanford, Stanford University Press, 2005.

Benite Zvi Ben-Dor, The Dao of Muhammad: A Cultural History of Muslims in Late Imperial China, Cambridge, MA, Harvard University Asia Center, 2005.

CHANG Qiming 常啟明, "Bai Chongxi jiangjun yu chengda shifan xuexiao pianduan" 白崇禧將軍與成達師範學校片段, in Zhongguo yisilan xiehui 中國伊斯蘭教 協會 (ed.), Chengde dacai: jinian chengda shifan chuangjian bashi zhounian xueshu yantaohui lunwen huibian 成德達才一一紀念成達師範創建八十週年 學術研討會論文匯編, Beijing, Zongjiao wenhua chubanshe, 2006, p. 179-189.

DiNG Mingjun丁明俊, “Ma Fuxiang minzu sixiang tanxi” 馬福祥民族思想探析, Huizu yanjiu 回族研究 3, 1996, p. 24-30.

- - , "Ma Fuxing yu xiandai huiru duihua" 馬福祥與現代回儒對話, Huizu yanjiu 回 族研究 4, 2002, p. 26-28.

Du Zhuoya 杜卓婹 \& WANG Hongyan 王紅岩, “Ningxia huizu nonghu he hanzu nonghu de shouru chayi chengyin fenxi” 寧夏回族農戶和漢族農戶的收入差異 成因分析, Xibei minzu xueyuan bao 西北民族學院報 2, 2003,p.41-44.

Gu Jiegang 顧頴剛, “Huijao de wenhua yundong” 回教的文化運動, Yugong 禹貢 (7) 4, 1937, p. 187-189.

Gu Wenshuang 谷文雙 et al., “Helongjiang xinshi jiaoyu shulue”黑龍江新式教育述 略, Huizu yanjiu 回族研究 1, 2002, p. 109-111.

Kurzman Charles, Modernist Islam, 1840-1940, Oxford, Oxford University Press, 2002.

He Yaozu 賀耀祖, [He Yaozu cable to Jiang Jieshi], August 22, 1934, Taipei, Guomindang dangshiguan (Nationalist Party Archive).

Hu Yunsheng 胡云生, Chuancheng yu rentong: henan huizu lishi bianqian yanjiu 傳承 與認同: 河南回族歷史變遷研究, Yinchuan, Ningxia renmin chubanshe, 2007.

Li Dechang 李德昌, “Zhoukou huizu jiaoyu de lishi xianzhuang yu fazhan duice” 周 口回族教育的歷史現狀與發展對策, Huizu yanjiu 回族研究 4, 1997, p. 49-52.

Lipmam Jonathan, Familiar Strangers: A History of Muslims in Northwest China, Seattle and London, University of Washington Press, 1997.

Liu Zhou 六洲, “Zhongguo huimin yiju guojia zhi guannian” 中國回民宜具國家之觀 念, Yиehua 月華 (1) 2, November 15, 1929, p. 2.

MA Bozhong 馬博忠, “Chengda shifan: musilin jiaoyu de dianfan” 成達師範：穆斯 林教育的典範, Musilin tongxun 穆斯林通訊 8, 2002, text online: http://www. 


\section{Mao Yufeng}

kyaz.com/islam/ReadNews.asp?NewsID=459 \& BigClassID=28\& SmallClassID $=26 \&$ SpecialID $=0$

- - “Tang Kesan yu chengda shifan” 唐柯三與成達師範, Zhongguo musilin 中國穆 斯林 5, 2004, p. 26-29.

- - , "Yuehua chuangshiren liren zhubian bianji shengping jianjie” 月華創始人歷 任主編編輯審評簡介, in Zhongguo yisilan xiehui 中國伊斯蘭教協會 (ed.), Chengde dacai: jinian chengda shifan chuangjian bashi zhounian xueshu yantaohui lunwen huibian 成德達才一一紀念成達師範創建八十週年學術研 討會論文匯編, Beijing, Zongjiao wenhua chubanshe, 2006, p. 97-122.

- - , “Huizu minren Mu Huating” 回族名人穆華亭, in Zhongguo yisilan xiehui 中 國伊斯蘭教協會 (ed.), Chengde dacai: jinian chengda shifan chuangjian bashi zhounian xueshu yantaohui lunwen huibian 成德達才一一紀念成達師範創建 八十週年學術研討會論文匯編, Beijing, Zongjiao wenhua chubanshe, 2006, p. 159-168.

- - , “Fa Jingxuan yu chengda shifan” 法鏡軒與成達師範, in Zhongguo yisilan xiehui 中國伊斯蘭教協會 (ed.), Chengde dacai: jinian chengda shifan chuangjian bashi zhounian xueshu yantaohui lunwen huibian 成德達才一一紀念成達師 範創建八十週年學術研討會論文匯編, Beijing, Zongjiao wenhua chubanshe, 2006, p. 203-214.

MA Songting 馬松亭, “Zhonguo huijiao yu Chengda shifan xuexiao” 中國回教與成 達師範學校, Yugong 禹貢 (5) 11, August 1, 1936, p. 1-14.

PANG Shiqian 龐士謙, “Quanguo qingzhensi hailifa jiaoyu ganliang chuyi” 全國清真 寺海里法教育改良媰議, Yuehua 月華 (16) 4-6, February 5, 1946, p. 7.

QIU Shusen 邱樹森 (ed.), Zhongguo huizu shi 中國回族史, 2 vols, Yinchuan, Ningxia renmin chubanshe, 1996.

WANG Jingzhai 王靜齋, “Jinshou huijiao yu aihu guojia” 敬守回教與愛護國家, Yuehua 月華 (2) 3, January 25, 1930, p. 1.

WANG Mengyang 王夢揚, “Yige you zhongguo huimin ziban de beiping chengda shifan xuexiao shimo jishi”一個由中國回民自辦的北平成達師範學校始末紀 實, in Zhongguo yisilan xiehui 中國伊斯蘭教協會 (ed.), Chengde dacai: jinian chengda shifan chuangjian bashi zhounian xueshu yantaohui lunwen huibian 成德 達才一一紀念成達師範創建八十週年學術研討會論文匯編, Beijing,Zongjiao wenhua chubanshe, 2006, p. 7-24.

XIN Wu 醒吾, “Huijiao buzhen de genben renshi” 回教不振的根本認識, Yuehua 月 華 (1) 3, November 25, 1929, p. 1-2.

Xu Xianlong 許憲龍, Zhuma junfa jituan yu xibei musilin shehui 諸馬軍閥集團與西 北穆斯林社會, Yinchuan, Ningxia renmin chubanshe, 2001.

YANG Zhaojun 楊兆鈞, Yunnan huizu shi 雲南回族史, Kunming, Yunnan renmin chubanshe, 1989.

ZHANG Ziwen 張子文, “Shuo wenzi zhi zunzhong”說文字之尊重, Jinghua xinbao 京 華新報, March 12, 1914.

Zhou Chuanbin 周傳斌, Xinhua xiangchuan de huizu jiaoyu 薪火相傳的回族教育, Yinchuan, Ningxia renmin chubanshe, 2008. 
ZHou Zhongren 周仲仁, “Jinan chengda shifan” 濟南成達師範, in Zhongguo yisilan xiehui 中國伊斯蘭教協會 (ed.), Chengde dacai: jinian chengda shifan chuangjian bashi zhounian xueshu yantaohui lunwen huibian 成德達才——紀 念成達師範創建八十週年學術研討會論文匯編, Beijing, Zongjiao wenhua chubanshe, 2006, p. 2-6.

\section{Chinese Character List}

ahong 阿言 (阿洪, 阿衡)

Bai Chongxi 白崇禧

Chengda shifan xuexiao 成達師範學校

Chengda wenhui 成達文匯

Chengshi yuekan 成師月刊

Dagongbao 大公報

Da Pusheng 達浦生

Fa Jingxuan 法鏡軒

Fan Changjiag 範長江

fanxue 蕃學

Feng Yuxiang 馮玉祥

Gu Jiegang 顧頡剛

guan dao sanpin bi fanjiao 官到三品必反教

guo 國

guojia guannian 國家觀念

guojia yishi 國家意識

guojie 國界

guowen 國文

Ha Decheng 哈德成

hailifan 海里凡

He Yaozu 賀耀祖

Hou Songquan 侯松泉

$\mathrm{Hu}$ Dengzhou 胡登洲

$\mathrm{Hu}$ Songshan 虎嵩山

hui 回

huimin 回民

huizu 回族

Jinan 濟南

jingru xiaoxue 經儒小學

jingshu yixue 經書義學

jingtang jiaoyu 經堂教育

jingtangyu 經堂語

kaixue ahong 開學阿言

Liu Zhi 劉智 


\section{Mao Yufeng}

Ma Bufang 馬步芳

Ma Fuxiang (Yunting) 馬福祥（雲亭）

Ma Hongkui 馬鴻逵

Ma Linyi 馬鄰翼

Ma Qi 馬麒

Ma Songting 馬松亭

manla 滿拉

minzu zhuyi 民族主義

Mu Huating 穆華亭

neidi 內地

Pang Shiqian 龐士謙

qingzhen xuetang 清真學堂

shidai jingshen 時代精神

shifan 師範

sixiang tongyi 思想統一

Sun Shengwu 孫繩武

Tang Kesan 唐柯三

Tianfang Dianli 天方典禮

Tianfang Xingli 天方性理

Wang Jingzhai 王靜齋

Wang Kuan 王寬

wangguo 亡國

xiandai 現代

Xingjiao jiuguo 興教救國

yijiao de bairen 異教的白人 Yuehua 月華

Zhang Ziwen 張子文

Zhongguo huimin中國回民

Zhonghua minzu 中華民族

zhongzu 種族

$\mathrm{zu}$ 族 